\section{OECD wants more science cooperation}

Paris

INTERNATIONAL sharing of scientific and technological advances is good in principle but difficult to achieve in practice. This was the conclusion of science and technology ministers when they met under the aegis of the Organisation for Economic Co-operation and Development (OECD) last October. Now, the OECD Council has drawn up a list of recommendations aimed at overcoming obstacles to greater international cooperation in research.

According to a recent OECD communiqué, the increasing contribution of private enterprise to basic science and technology research in developed countries, although advantageous on a national level, brings with it an unwillingness to share findings unless copyright and patent rights are respected. Unfortunately, not all OECD member states subscribe to international codes of conduct designed to protect these rights.

The OECD recommends three major ways to improve the flow of information across national boundaries: removal of trade barriers; promotion of basic research and dissemination of findings; and increased international cooperation through joint research programmes.

Specifically, the council recommends that member countries promote advances in scientific and technological knowledge by supporting basic research and maintaining up-to-date research facilities; promoting the education and advanced training of future generations of scientists, engineers and technical personnel and facilitating the exchange of students and scientists between member countries; facilitating the international mobility of scientists and engineers, and in particular their access to major basic research facilities; promoting the dissemination of the results of basic research, particularly through publication in internationally available scientific literature, access to databanks and networks, and open participation in scientific meetings.

So-called 'developing' countries are often at a disadvantage, not only because of limited facilities for advanced research, but because access to computer networks may be non-existent or restricted.

To tackle the problem of technology transfer, the council not only recommends the "circulation, exchange and trade of technologies", but also the promotion of "improved universal protection of intellectual and industrial property rights". The difficulty here, as experience has shown, is that it is often impossible to sanction organizations that flout these rights in countries which do not recognize international copyright and patent laws.

Peter Coles

Science research a key issue in French electoral campaigns

Paris

"IF France wants to succeed, research will have to become the Republic's favourite child", says President François Mitterrand, in the run-up to the May presidential elections. Mitterrand's adversary, neo-gaullist Prime Minister Jacques Chirac, agrees, but the policies (and track records) of the two could not be more different.

By bringing the issue of public-sector spending on research to the forefront of his electoral campaign, Mitterrand has embarrassed Chirac. When the socialists lost power in 1986, Chirac's government set about dismantling the country's publicsector research infrastructure. Over half of the 'savings' in public spending were found within the research budget, annual recruitment, and promotions within the Centre National de la Recherche Scientifique (CNRS) were suspended, and ANVAR, the government agency promoting technology transfer from universities to industry, was threatened with closure.

Chirac would have preferred not to be reminded of this 'Dark Age' period. Instead, he claims increases in state spending on research of 8 per cent in 1987 and of 10 per cent in 1988. But the increases are only apparent when defence and civil research spending are lumped together. If the extra FF33,000 million ( $\{3,200$ million) allocated for defence research is ignored, spending on civil research has increased by only 2.3 per cent since 1986 which, with inflation, amounts to a slight net decrease.

Similarly, Chirac can point to the creation of 150 new research posts in the public sector this year. But 288 posts have been suppressed, while the temporary suspension of CNRS recruitments in 1986 and 1987 makes it difficult to see what the real annual trend is.

If Chirac's initially draconian attack on public-sector research was halted when, in late 1986, his research minister, Alain Devaquet, was forced to resign in the face of mounting unrest in universities and research centres, the renaissance of research as a government priority has been founded on a demand for more support from industry. According to Chirac, the private sector will need to contribute an extra FF25,000 million towards research by 1995 if France is to keep up with foreign competition in technology.

To stimulate industry's share of the research bill, the present research minister, Jacques Valade, has voted FF500 million of annual tax incentives, industrybased research scholarships and new mechanisms for collaboration between private and public-sector scientists.

Mitterrand also wants to see France increase its research spending, but his electoral campaign, published in full in the French daily newspaper, Le Monde, last week, is vague when it comes to concrete measures to achieve this. Between 1979 and 1985 , public sector spending on research increased from 1.81 per cent to 2.25 per cent of gross domestic product (GDP), the socialists having continued a trend started under Raymond Barre's conservative government. Mitterrand feels that a figure of 3 per cent of GDP should be aimed for by 1992. Although it was the socialists who introduced a system of tax incentives for industrial research, it is within state-supported research that he

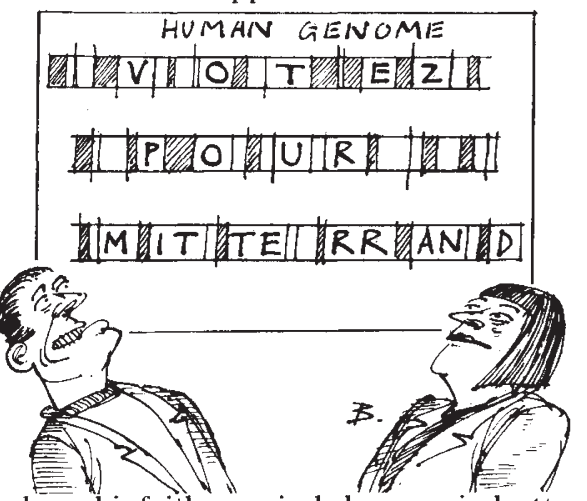

places his faith, precisely because industry "is not pulling its weight"

Under the present government, the emphasis is firmly on research with clear short-term commercial applications. Mitterrand, however, sees the role of basic research as fundamental. "Let us neither be afraid of nor criticize research that finds nothing. Out of the mass of investigations springs discovery, the research that finds." Mitterrand cites research to sequence the human genome, which will "cost less than a trip to the Moon". Yet, he adds, "no country in Europe devotes a serious part of its budget" to this quest.

Mitterrand has not been slow to remind voters that it was he who, launched the European Eureka technology research initiative, as an alternative to joining the US 'star wars' research programme.

Chirac has called Mitterrand's rhetoric "woolly" and "misinformed", but it has been effective - the major daily newspapers have given considerable space to the volte face in Chirac's research policy. If Mitterand is re-elected on 8 May, as public opinion polls and his success in the primaries suggest will happen, he will still have to contend with a right-wing majority in government. He would undoubtedly want to name a new prime minister but he could find it difficult to reintroduce the public spending increases so unpopular with the conservative majority. Peter Coles 